\title{
Imperative Models and Functions in Environmental, Organizational and Individual Synergy with the Concept of Harmonious Engagement
}

\author{
Retno Setyowati, Suharnomo, Indi Djastuti
}

\begin{abstract}
This study seeks to analyze the concept of harmony engagement in the work environment, and build a model of the relationship between organizational justice, harmonious engagement, which is assumed to affect performance. In addition, this study also seeks to empirically analyze the results of previous research on the importance of the concept of harmonious relations by taking the field of nursing work. By using a descriptive analytical approach, and meta-analysis, the results of the study revealed the importance of establishing harmonious relationships and the need for environmental, organizational and individual synergy with the concept of Harmonious Engagement. Furthermore, the synergy scheme must consider the imperative function in the management of human resources in the workplace which includes objectives, integration, latency and adaptation processes. Theoretically, this imperative function if properly placed then it will maintain the equilibrium balance of the organization (or each individual system) when changes occur and the process of change in the organizational environment.
\end{abstract}

Keywords: Environmental, Organizational and Individual Synergy, Harmonious Engagement, organizational justice, $O C B$.

\section{INTRODUCTION}

$\mathrm{O}_{\mathrm{r}}$ ganization is a social system where humans are the main factors of effectiveness and efficiency. An organization cannot succeed without one's efforts and commitment (Mohammad Mosadegh Rad and Hossein Yarmohammadian 2006). Every organization in achieving its goals requires cooperation, mutual assistance, mutual advice, attitudes that show sincerity, altuism and other matters related to individual behavior in the organization. A dynamic organizational situation requires each individual to be able to adjust. Organization as a social environment requires flexibility in work where every individual in it is able to accept and overcome the demands of the organization and its social environment. The behavior of each individual in the organization is a "lubricant" in the organization's social machinery.

The development of human resource management is now at the stage of human capital. Human resources are no longer as a support but rather as a key holder or as an asset of

Revised Manuscript Received on November 15, 2019.

Retno Setyowati*, Diponegoro University, Semarang

Suharnomo, Diponegoro University, Semarang

Indi Djastuti, Diponegoro University, Semarang

organizational success. Human resources as social beings are given uniqueness and strengths that can be a supporting factor for organizational success including having a sense, feelings, desires, abilities, skills, knowledge, encouragement, power, and work that is not the same between one individual with another individual. No matter how sophisticated the tools, machines, technology and other factors available to the organization, it is impossible to realize the goals of the organization without regard to aspects of human resources in the organization. the differences that exist within the company, if organized properly will be the strengths and advantages of the organization and be able to create a good teamwork so that it can answer the challenges of change in the current era of globalization. The role of human resources as an asset towards organizational success requires engagement between fellow employees, employees and leaders / employees, employees with the work environment and employees with the organization. Organizational performance will be more effective when human resources are well managed. The effectiveness of organizational performance can be seen from the division of labor and work relationships between units, sub-systems, sub-systems so that team collaboration can be created between work units within the organization. Positive behavior towards colleagues is shown in team collaboration which is a form of organizational citizenship behavior (OCB). In this context, this study seeks to analyze the concept of harmony in the work environment, and build a model of the relationship between organizational justice, harmonious engagement, which is assumed to affect performance. In addition, this study also seeks to empirically analyze the results of previous research on the importance of the concept of harmonious relations by taking the field of nursing work. Because environmental harmony is influenced by organizational justice and its influence on Organizational Citizenship Behavior / OCB, this study also analyzes the results of studies from various previous studies regarding the effect of organizational justice, employee engagement and employee harmony on employee performance in several research objects in the field of nursing resource management for shows the importance of forming harmonious relationships and the need for environmental, organizational and individual synergy with the concept of harmonious engagement. 


\section{Imperative Models and Functions in Environmental, Organizational and Individual Synergy with the Concept of Harmonious Engagement}

\section{ORGANIZATIONAL JUSTICE AND ORGANIZATIONAL CITIZENSHIP BEHAVIOR}

Everyone will engage in reciprocal, mutually beneficial relationships only when they trust their partners (Miles, 2012). Likewise the relationship between employees and companies is a form of social exchange, not only based on economic exchange but also includes social exchange. A manager should help employees to understand and trust any values in the company, and give awards to employees both economic rewards (compensation, vacation time or leave, etc.) or social rewards (attention, appreciation, friendship, and others that do not incur company costs).

Organizational justice is also one indicator that affects the reciprocal relationship and mutual trust between employees and the company (Ridaryanto, 2019). Employees who feel they have been treated fairly, it is appropriate to give feedback in the form of positive organizational attitudes and behavior that support organizational goals, namely in the form of organizational commitment and OCB (Widyaningrum, 2010).

By giving fair treatment to employees, the company will get positive benefits that support the company's effectiveness, among others in the form of improved performance, improved work quality, decreased turnover, and improved customer service. Frederick Herzberg (1976) states there are two sets of factors or conditions that influence human behavior in an organization. These factors are hygiene (maintenance) and motivation (satisfying) factors (Robbins and Coulter 2007). The hygiene factor is a factor that gives a neutral feeling when things arise such as company regulations and policies, the nature of supervision, interpersonal relations, working conditions and safety as well as salary and benefits.

Emami et.al. (2012) said that there are several variables that influence OCB employee behavior, including clarity of regulations, leadership, organizational commitment, organizational justice, and the nature of each individual. This means that OCB is a part of individual behavior, in this case employees are very important in carrying out each employee's duties and obligations, which will lead to the company's success.

Good OCB behavior of employees will lead to feelings of emotional involvement between employees with work and organization, as well as employee motivation to provide the best ability to help the company's success through concrete actions (McLeod, 2009). This can help companies in achieving long-term goals so that the company can excel in competing with other companies (Little, 2006).

OCB is an expression of one's motivation in an organizational context. Actual actions that can be seen in the work linkup as OCB forms at the individual level include being willing to give a ride home, giving advice on one's work, helping to load or manage paper in a communal printer. When someone wants to give advice on the employee recruitment process, giving suggestions for improving work facilities or willing to work late at night without expecting anything in return is a form of OCB action at the organizational level.

OCB behavior that arises among employees will be very important for a company to strengthen teamwork within the company. Through this OCB behavior, companies can improve company effectiveness, further improve service performance to consumers and the company climate will be well maintained because the relationships between employees or between employees and superiors are well established.

Based on a study conducted by Podsakoff (2000), OCB manifestations are helping behavior, altruism, courtesy, peacemaking, interpersonal helping, sportmanship, Organizational Loyalty, spreading goodwill, organizational compliance, generalized competency, organizational obedience, job dedication, individual initiative, conscientiousness, personal industry, civic virtue, organizational participation, protecting the organization and self development. In line with Podsakoff, Organ (2006) underlines the behavior of OCB in five forms of action namely altruism, sportmanship, courtesy, civic virtue and conscientiousness.

Basically the OCB behaviors expressed by both Podsakoff and Organ are a tangible form of the nature of Indonesian society. Altruism (helping others), sportmanship (sportsmanship / tolerance / sincerity), civic virtue (virtue) and conscientiousness (caution) can be seen in daily activities. This is one form of national culture in this country. Fluctuations in the behavior of each person based on their abilities, creativity and innovation within the organization will not just happen without cultural influence. Culture is formed from how one sees events in the organization. Culture in the organization which is the core value of the organization will be strong when held in high esteem and held by each individual. The more individuals in an organization who accept core values, the greater their commitment to the organization (Robbins \& Judge, 2013).

This study tries to analyze how the role of organizational justice on performance when influenced by the dimensions of employee attitudes, proactive climate and harmonious employee engagement orientation. The condition of Indonesia's collectivist culture influences each individual in their actions. When individuals feel that they get injustice at work, proactive climate and employee behavior (OCB) will play a role in reducing conflict, respecting others, being wise and prudent in solving problems and sincerity in attitude so as to create harmony between employees that will bind employees to the organization.

\section{ORGANIZATIONAL JUSTICE AND ORGANIZATIONAL COMMITMENT}

Organizational Justice has a positive influence on organizational commitment (Pareke \& Suryana, 2009; Jawad, Raja, Abraiz, \& Tabassum, 2012; Yazicioglu \& Topaloglu, 2009) and performance (Nasurdin \& Khuan, 2007; Suliman \& Kathairi, 2012). A study by Shahram Gilaninia and Rahim Abdesonboli (2011) shows that there is a positive relationship between organizational justice and OCB. Most respondents consider that the fairness dimension of the organization (salary, wages, bonuses and promotions) is very low. Although procedural fairness is very low but this does not affect employee attitudes because supervisors behave well and are communicative towards employees so that employees continue to perform well. 
Research in the domain of OCB is often done, but not many explore the relevance of OCB to individuals and organizations (Aykut Berber and Yasin Rofcanin, 2012).

Krishnan (2018) provides empirical evidence to link the perceived organizational perceptions of employees with job performance. His research found great support for the direct effect of organizational justice on employee performance. Companies that provide focus and attention in providing a conducive work environment that increases the distributive equity perceived by employees will ultimately improve the work performance of each employee.

Greenberg (1987) argues that organizations that fail to provide fair treatment will receive negative reactions from their workers. The Greenberg Study (1987) seems to coincide with the results of Ibrahim's study (2018), found a moderate negative relationship between the dimensions of organizational justice and counterproductive work behavior. Therefore it is recommended that a training program be implemented to promote awareness among employees about the negative consequences resulting from counterproductive work behavior.

Organizational justice in theory is a positive proposition, so ideally always has a positive effect. But the study of Greenberg (1987) and Ibrahim (2018) above shows that it does not always occur ideally. Akram (2016) found a significant positive relationship between distributive justice and employee job satisfaction but there was a significant negative relationship between procedural fairness and job satisfaction among banking sector employees.

Akram's research confirms that organizational justice is not only seen from its output, such as wages that are in accordance with employee competencies, but it is important to see how the distribution is made by their superiors. Employees who do not have the power of voice in making decisions that apply downward as orders are negatively related to satisfaction.

Organizational justice has aspects that have unequal effects on employee performance. Kalay (2016) found that from three aspects of organizational justice, namely distributive, procedural and interactional justice. Only the distributive justice aspect of organizational justice is an important determinant of employee performance, while procedural and interactional justice does not have a significant impact on employee performance.

The results of Ari Warokka et al (2012) as a whole prove that Organizatoinal Justice has no effect on employee performance. Only Interactional Justice has an influence on employee performance. Meanwhile Procedural justice and Distributive justice have no effect on employee performance.

\section{IMPERATIVE FUNCTIONS IN ENVIRONMENTAL, ORGANIZATIONAL AND INDIVIDUAL SYNERGIES}

As individuals who are in an environment will be directly involved in the existing social system. Talcott Parsons (1951) states that humans from individuals, families to organizations need four absolute components called the Imperative Function.

1. Purpose. The organization realizes and understands its main purpose and how to achieve it. Likewise with every individual in the organization. hence the organization will draw up a well-organized and well-planned plan where the success of the plan will depend on how individuals in the organization play a role in the system.

2. Integration. Within the organization there are various subsystems and different groups that influence each other. Groups and subsystems then integrate. The integration process will make each individual cooperative in cooperation.

3. Latency (invisible condition). Latency is something that is not visible, but is an important part of the organizational aspects where patterns in the system emerge and are maintained and are inherent processes in managing conflict within the organization. This is organizational culture.

4. Adaptation process. Is a condition where the organization can change or become better to maintain its equilibrium as how each part can change to adjust for external changes.

These four imperative functions, if properly placed, will maintain the equilibrium balance of the organization (or each individual system) when changes occur and the process of change. In achieving individual and organizational goals, every aspect will be integrated and mutually supportive. As an organization can not be separated from the individuals within it and individuals within the organization can not be separated from other individuals and cultures that exist in the organization.

Figure 1. Scheme of Environmental, Organizational and Individual Synergy with the concept of Harmonious Engagement

\begin{tabular}{|c|c|c|c|c|}
\hline \multicolumn{5}{|c|}{ ENVIRONMENT } \\
\hline $\begin{array}{l}\mathbf{O} \\
\mathbf{R} \\
\mathbf{G} \\
\mathbf{A} \\
\mathbf{N} \\
\mathbf{I} \\
\mathbf{Z} \\
\mathbf{A} \\
\mathbf{T} \\
\mathbf{I} \\
\mathbf{O} \\
\mathbf{N}\end{array}$ & $\begin{array}{l}\text { Salary } \\
\text { Promotion } \\
\text { Decision-making } \\
\text { Regulation }\end{array}$ & $\begin{array}{l}\text { Team } \\
\text { Cooperation } \\
\text { Work } \\
\text { atmosphere }\end{array}$ & $\begin{array}{l}\text { Quality } \\
\text { Quantity } \\
\text { Period of } \\
\text { time } \\
\text { Presence }\end{array}$ & $\begin{array}{l}\mathbf{O} \\
\mathbf{R} \\
\mathbf{G} \\
\mathbf{A} \\
\mathbf{N} \\
\mathbf{I} \\
\mathbf{Z} \\
\mathbf{A} \\
\mathbf{T} \\
\mathbf{I} \\
\mathbf{O} \\
\mathbf{N}\end{array}$ \\
\hline & $\begin{array}{c}\text { ORGANIZATION } \\
\text { AL JUSTICE }\end{array}$ & $\begin{array}{c}\text { HARMONIO } \\
\text { US } \\
\text { ENGAGEM } \\
\text { ENT }\end{array}$ & $\begin{array}{l}\text { PERFOR } \\
\text { MANCE }\end{array}$ & \\
\hline $\begin{array}{l}\mathbf{I} \\
\mathbf{N} \\
\text { D } \\
\mathbf{I} \\
\mathbf{V} \\
\mathbf{I} \\
\mathbf{D} \\
\mathbf{U} \\
\mathbf{A} \\
\mathbf{L}\end{array}$ & $\begin{array}{l}\text { Respect } \\
\text { Attention } \\
\text { Equality } \\
\text { Concern }\end{array}$ & $\begin{array}{l}\text { Self } \\
\text { condition } \\
\text { Affiliation } \\
\text { Tolerance } \\
\text { Empathize } \\
\text { Compromise }\end{array}$ & $\begin{array}{l}\text { Creativity } \\
\text { Initiative } \\
\text { Reliability }\end{array}$ & $\begin{array}{l}\mathbf{I} \\
\mathbf{N} \\
\mathbf{D} \\
\mathbf{I} \\
\mathbf{V} \\
\mathbf{I} \\
\mathbf{D} \\
\mathbf{U} \\
\mathbf{A} \\
\mathbf{L}\end{array}$ \\
\hline \multicolumn{5}{|c|}{ ENVIRONMENT } \\
\hline
\end{tabular}

V. HARMONIOUS RELATIONSHIP WITH OCCUPATIONS WITH HIGH ATTACHMENT: META ANALYSIS ON NURSE WORK 


\section{Imperative Models and Functions in Environmental, Organizational and Individual Synergy with the Concept of Harmonious Engagement}

Now career has become something that is not easy to predict. Career becomes one's experience in making continuous compromises for the benefit of his work and aspects outside of work related to career stages and different stages of life (Arthur et al, 2005). The high level of turnover is not a small thing that can be avoided. Many things affect the high turnover. The logic is that employees can turn away and leave the workplace if their needs are not met.

Teng, et al. (2007) states that professional commitment shows: (1) trust and acceptance of professional goals and professional values, (2) a desire to exert great effort on behalf of the profession and (3) a strong desire to maintain professional membership. Therefore, it can be concluded that professional commitment is an employee's emotional attachment to his profession and wants to remain part of the profession and work hard in an effort to achieve professional goals (Setyowati et al., 2017).

Work involvement has become an important issue in nursing related to the prediction of commitment and intention to stay in the company and its profession (Tsai, et al, 2015). Kuruüzüm, et al. (2008) explained that work involvement is psychologically identifying a person with his work, actively participating and work is considered as an important part of his life.

Chen and Chiu (2009) also mentioned that employees with a high sense of work involvement would be more independent and confident, they not only did their jobs according to the job assignments needed by the company but were also more likely to do their jobs according to their perceptions of performance alone.

Dubrenil, Forest and Courcy (2014) stated that employees perceive performance as a form of activity that involves strength. Strengthening is a form of responsibility for optimizing performance so that employees can work with enthusiasm and for a long period of time. The greater the performance given, the employee will be more pro-active in the work environment.

A nurse who has a high work involvement will try to provide the best, working to the maximum, will be happy to follow the professional code of ethics and hospital policies. But in practice, the influence of workload and environmental situations can affect the quality of employee involvement in the organization. For example, in the profession of doctors, the law in Indonesia allows a practicing doctor in 3 (three) places. The number of places this practice makes a doctor will split the focus of his task. So it has the potential to reduce the level of involvement in certain organizations or certain places of practice. The hospital implements a certain reward system for medical staff and paramedical staff, where for each profession there is a different reward. For nurses themselves, the amount of reward received will differ (depending on the part / workload of patient services). This is what then triggers the emergence of the perception of injustice in the reward system so that it makes a decrease in employee involvement. The business phenomenon that arises is when management tries to create conditions that will increase employee involvement but the results are not in line with expectations.

Smulder (2006) states that some jobs that require high work engagement include teachers, entrepreneurs, and nurses. Some of these jobs have in common, namely work that involves the quality of service as its main capital. However, the ratio between nurses and patients they care for is unbalanced. WHO set the ideal ratio of nurses to patients is 1 : 200, while WHO noted the ratio between nurses and patients in Indonesia is still far from WHO standards, which is equal to 1: 375 .

Urmila Rani Srivasta (2015) who analyzed Organizational Justice, Job Satisfaction, Organizational Commitments on Professional Workers in the field of health services at Government Hospitals in India stated that distributive justice and informational justice did not affect job satisfaction. Informational justice alone that strongly influences organizational commitment. Gender, marital status and length of work do not affect organizational commitment. Salwa Attia Mohamed (2014) who analyzed the correlation between Organizational Justice, and Quality Performance of Health Officers at the General Hospital in Fayoum-Egypt states that health workers' perceptions of organizational justice affect the quality of their performance. As procedural fairness increases, the quality of performance of health workers also increases.

Hanim Seyrek and Dilek Ekici (2017) analyzed with regression between Organizational justice, type of hospital, psychologically violent behavior in Educational Hospitals and Private Hospitals in Turkey, and found that nurses who felt injustice did not affect behavior and performance. Type of Hospital (Educational Hospital).

Suzuki et al (2017) with linear model statistics with conflict analysis with physicians, death and dying, inadequate preparation, lack of support, conflict with other nurses, uncertainty concerning, organizational justice in Nurses at General Hospital in Japan found that distributive justice influences preparation which is not adequat by nurses. Organizations with high distributive justice tend to put high stress on inadequate preparation.

Khalifa and Awad (2018) analyzed with Regression between Organizational Justice, OCB in Surgical Medical Nurses at Teaching Hospital in Egypt, finding that In interactional justice, student nurses are treated with respect and dignity. Student nurses feel they lack justice related to incentives, unequal efforts and salaries, lack of involvement in decision making. Organizational Justice strongly influences OCB nurses.

\section{CONCLUSION}

The results of previous studies on the influence of Organizational Justice, employee engagement and employee harmony on employee performance in several research objects in the field of nursing resource management show the importance of establishing harmonious relationships and the need for environmental, organizational and individual synergy with the concept of Harmonious Engagement. The results of the study show different results and show different problems related to organizational justice. The business phenomenon that emerged in the preliminary observations of this study in several workplaces in various business fields showed that there were employee reactions in responding to organizational 
justice. Employee responses to organizational justice vary, from the decline in performance (disciplinary and turnover), negative behavior (bullying) to the appearance of employee demonstrations.I

This study proposes a model of the relationship between organizational justice, harmonious engagement, which is assumed to affect performance. Basically, the synergy scheme must consider the imperative function in the management of human resources in the workplace. The imperative functions include the objectives, integration, latency and adaptation processes. These four imperative functions, if properly placed, will maintain the equilibrium balance of the organization (or each individual system) when changes occur and the process of change. In achieving individual and organizational goals, every aspect will be integrated and mutually supportive. As an organization cannot be separated from the individuals within it and individuals within the organization cannot be separated from other individuals and cultures that exist in the organization.

\section{REFERENCES}

1. Akram U., Kaleem Khan M., Yixin Q., etc., (2016). Impact of Organizational Justice on Job Satisfaction of Banking Employees. European Journal of Business and Management, Vol.8, No.16, ISSN: 2222-2839

2. Arthur, A. R. (2005). When stress is mental illness: A study of anxiety and depression in employees who use occupational stress counselling schemes. Stress And Health: Journal Of The International Society For The Investigation Of Stress, 21(4), 273-280.

3. Berber, A., \& Rofcanin, Y. (2012). Investigation of organization citizenship behavior construct a framework for antecedents and consequences. International Journal of Business and Social Research, 2(4), 195-210.

4. Chen, C. C., \& Chiu, S. F. (2009). The mediating role of job involvement in the relationship between job characteristics and organizational citizenship behavior. The Journal of social psychology, 149(4), 474-494

5. Dubreuil, P., Forest, J., \& Courcy, F. (2014). From strengths use to work performance: The role of harmonious passion, subjective vitality, and concentration. The Journal of Positive Psychology, 9(4), 335-349.

6. Gillessen, S., Attard, G., Beer, T. M., Beltran, H., Bossi, A., Bristow, R., ... \& Daugaard, G. (2018). Management of patients with advanced prostate cancer: the report of the Advanced Prostate Cancer Consensus Conference APCCC 2017. European urology, 73(2), 178-211.

7. Goudarzvandchegini, M., Gilaninia, S., \& Abdesonboli, R. (2011). Organizational justice and organizational citizenship behavior case study: Rasht public hospitals. International Journal of Business Administration, 2(4), 42.

8. Herzberg, F. (1976). The managerial choice: To be efficient and to be human. Irwin Professional Publishing.

9. Ibrahim Saleh S.,A. The Impact of Organizational Justice on the Counterproductive Work Behavior (CWB): A Field Study Conducted in the Jordan Customs Department (JCD). International Journal of Business and Social Science Volume 9, No 1.

10. Kalay, F. (2016). The impact of organizational justice on employee performance: A survey in Turkey and Turkish context. International Journal of Human Resource Studies, 6(1), 1-20.

11. Khalifa, S.M.A., \& Awad, N.H.A.(2018). The Relationship Between Organizational Justice And citizenship Behavior As Perceived By Medical-Surgical Care Nurses. IOSR Journal of Nursing and Health Science (IOSR-JNHS) 7(4), 31-37

12. Krishnan K., Wei Loon K, Azreen Nur F, \& Alim Nur S.,Y. (2018). Examining the Relationship between Organizational Justice and Job Performance. International Journal of Academic Research in Business and Social Sciences, Vol. 8 , No.3, ISSN: 2222-6990.

13. Kuruüzüm, A., Anafarta, N., \& Irmak, S. (2008). Predictors of burnout among middle managers in the Turkish hospitality industry. International Journal of Contemporary Hospitality Management, 20(2), 186-198.
14. Little, B., \& Little, P. (2006). Employee engagement: Conceptual issues. Journal of Organizational Culture, Communications and Conflict, 10(1), 111-120.

15. McLeod, J., \& Thomson, R. (2009). Researching social change: Qualitative approaches. Sage publications.

16. Miles, J. A. (2012). Management and organization theory: A Jossey-Bass reader (Vol. 9). John Wiley \& Sons.

17. Mohamed, S. A. (2014). The relationship between organizational justice and quality performance among healthcare workers: A pilot study. The Scientific World Journal, 2014

18. Pareke, F. J., \& Suryana, P. (2009). Hubungan Kausalitas antara Keadilan Organisasional, Kepuasan Kerja, dan Komitmen Organisasional. Trikonometrika 8(2), 98-102.

19. Ridaryanto, P. (2019). Validating Constructs of Procedural Justice Based on Confirmatory Factor Analysis for Behavioral Accounting Scientific Research. International Journal of Scientific \& Technology Research 8(8), 513-516.

20. Setyowati, R., Priyotomo, P., \& Suharnomo, S. (2017). Investigating organizational commitment among medical doctors, hospital nurses and two other professional jobs: A systematic review. Global Journal of Health Science, 9(12).

21. Seyrek, H., \& Ekici, D. (2017). Nurses' Perception of Organisational Justice and its Effect on Bullying Behaviour in the Hospitals of Turkey. Hospital Practices and Research, 2(3), 72-78.

22. Smulders, P. G. (2006). Worklife in the Netherlands. Hoofddorp: TNO

23. Srivastava, U. R. (2015). Multiple dimensions of organizational justice and work-related outcomes among health-care professionals. American Journal of Industrial and Business Management, 5(11), 666

24. Teng, C. I., Shyu, Y. I. L., \& Chang, H. Y. (2007). Moderating effects of professional commitment on hospital nurses in Taiwan. Journal of Professional Nursing, 23(1), 47-54

25. Tsai, C.-Y., Horng, J.-S., Liu, C.-H., Hu, D.-C. (2015). Work environment and atmosphere: The role of organizational support in the creativity performance of tourism and hospitality organizations. International Journal of Hospitality Management, 46(1), 26-35.

26. Warokka, A., Abdullah, H. H., \& Duran, J. J. (2012). Ownership structures and firm performance: Does East Asian corporate governance recovery work? World Review of Business Research, 2(1), 18-35.

27. Widyaningrum, M. E. (2010). Pengaruh Keadilan Organisasi terhadap Kepuasan Kerja, Komitmen dan Organizational Citizenship Behavior Pegawai (Studi Kasus di Rumah Sakit Bersalin Pura Raharja Surabaya) Tahun 2009. Jurnal Ekonomi dan Bisnis Airlangga (JEBA) Journal of Economics and Business Airlangga, 20(1). 